\title{
Socioeconomic factors and severity of periodontal disease in adults (35-44 years). A cross sectional study
}

\author{
José-Manuel Almerich-Silla ${ }^{1}$, Pedro J. Almiñana-Pastor ${ }^{2}$, Montserrat Boronat-Catalá ${ }^{2}$, Carlos Bellot-Arcís ${ }^{3}$, \\ José-María Montiel-Company ${ }^{4}$
}

\author{
${ }^{1}$ Tenured lecturer, Preventive Dentistry Teaching Unit, Department of Stomatology, Faculty of Medicine and Dentistry, University \\ of Valencia (Spain) \\ ${ }^{2}$ Grado en Odontología [equivalent to BDS],, Specialist Master of Periodontics, Department of Stomatology, Faculty of Medicine \\ and Dentistry, University of Valencia (Spain) \\ ${ }^{3} \mathrm{PhD}$, Associate lecturer, Orthodontics Teaching Unit, Department of Stomatology, Faculty of Medicine and Dentistry, University \\ of Valencia (Spain) \\ ${ }^{4}$ Post-doctoral contract lecturer, Preventive Dentistry Teaching Unit, Department of Stomatology, Faculty of Medicine and Den- \\ tistry, University of Valencia (Spain)
}

\section{Correspondence:}

Departament d'Estomatologia

Universitat de València

C/ Gascó Oliag, 1, 46010-Valencia

carlos.bellot@uv.es

\begin{abstract}
Almerich-Silla JM, Almiñana-Pastor PJ, Boronat-Catalá M, Bellot-Arcís C, Montiel-Company JM. Socioeconomic factors and severity of periodontal disease in adults (35-44 years). A cross sectional study. J Clin Exp Dent. 2017;9(8):e988-94. http://www.medicinaoral.com/odo/volumenes/v9i8/jcedv9i8p988.pdf

Received: 10/05/2017

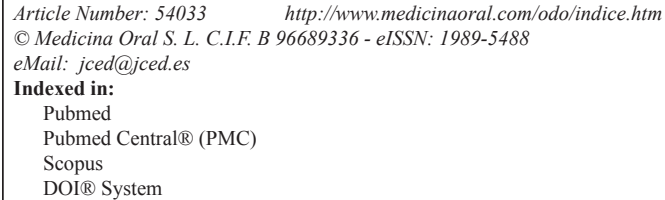

\begin{abstract}
Background: Periodontal disease or periodontitis is an inflammatory disease with a hight prevalence. According to the last oral health survey of the Spanish population, between $24 \%$ and $37 \%$ of Spaniards aged over 35 years have periodontitis and $6 \%$ to $10 \%$ of the adult population have deep periodontal pockets. The aim of this study was to determine the association between risk factors and the presence of periodontal pockets in the adult population. Material and Methods: A cross sectional or prevalence study of a representative sample of the adult population of the Valencia region was designed. The sample was recruited at 35 health centres, The study was conducted in November and December 2006 under standardized conditions as regards light sources, equipment and instruments and the position of the three previously calibrated dentist examiners.

Results: The sample examined consisted of 733 individuals (220 men and 513 women). Measured by the CPI, 13\% were healthy and $5.5 \%$ presented bleeding. The prevalence of calculus was $59.3 \%$, that of $3.5-5.5 \mathrm{~mm}$ pockets was $15.8 \%$ and that of pockets deeper than $5.5 \mathrm{~mm}$ was $4.6 \%$. Almost half the sextants were healthy (2.89), 0.61 presented bleeding and 1.74 presented calculus. The mean number of sextants affected by $3.5-5.5 \mathrm{~mm}$ pockets was 0.46 and 0.07 presented deep pockets $(>5.5 \mathrm{~mm})$. An adjusted multiple logistic regression model with the presence of periodontal pockets as the dependent variable showed that the significant independent variables were low social class $(\mathrm{OR}=1.81)$, smoking $(\mathrm{OR}=1.68)$, primary education $(\mathrm{OR}=1.57)$, male gender $(\mathrm{OR}=1.56)$ and age $(\mathrm{OR}=1.08)$. The other study variables were not significant in this model.
\end{abstract}


Conclusions: socioeconomic factors such as primary education and low social class, as well as gender, age and smoking, were found to be associated to a significant degree with greater prevalence of periodontal disease in the adult population.

Key words: Periodontal disease, adults, socioeconomic factors, periodontal pockets, cross sectional study.

\section{Introduction}

Periodontal disease or periodontitis is an inflammatory disease of the tissues that support the teeth, caused by specific microorganisms or groups of microorganisms, which results in progressive inflammatory destruction of the periodontal ligament and the alveolar bone and the formation of periodontal pockets, or receding gums, or both. The clinical sign that distinguishes gingivitis from periodontitis is the loss of attachment that occurs in periodontitis (1). According to the 2015 oral health survey of the Spanish population, between $24 \%$ and $37 \%$ of Spaniards aged over 35 years have periodontitis and $6 \%$ to $10 \%$ of the adult population have deep periodontal pockets (2).

Today, the diseases that affect the periodontium continue to be classified according to the proposal made by Armitage in 1999 (3). This classification divides the different clinical entities into the following major groups: gingival diseases, chronic periodontitis, aggressive periodontitis, periodontitis as a manifestation of systemic diseases, necrotising periodontal diseases, abscesses of the periodontium, periodontitis associated with endodontic lesions, and developmental or acquired deformities and conditions $(3,4)$.

The clinical signs used to diagnose periodontal disease are probing depth, bleeding on probing, and clinical attachment level.

Periodontal disease presents multi-factorial aetiology (5). The main risk factors for its progression are the presence of plaque, calculus and gingivitis, although many studies have shown that the these clinical factors alone are not sufficient for loss of attachment to appear (5-8). One of the environmental factors most associated with the progression of periodontal disease is smoking. Smokers are 2 to 7 times more likely to suffer periodontitis. Heavy smokers are twice as likely to present loss of attachment and bone loss than light smokers. Diabetes is another risk factor for periodontitis and poor control of diabetes in the presence of calculus is associated with a higher frequency of periodontal pockets $\geq 4 \mathrm{~mm}(9,10)$. Other factors related to periodontal disease are genetic factors, ethnicity, advanced age, male gender, depression, traumatic occlusion, osteoporosis, the presence of red complex bacteria (Porphyromona Gingivalis, Tanarella Forsythus, Treponema Denticola) and Prevotella Intermedia, low educational level and lack of dental care. In the presence of heavy accumulations of calculus, they are associated with a loss of periodontal support and may be considered indicators of a risk of periodontitis (11).

The aim of this study was to measure the association between different risk factors and the presence of periodontal pockets in the adult population.

\section{Material and Methods}

A cross sectional or prevalence study of a representative sample of the adult population of the Valencia region was designed. Out of the 111 health centres in the Valencia Region of Spain, 35 were selected at random. At these health centres, persons aged between 35 and 44 years who visited the health centre for a non-dental reason were asked whether they would agree to being examined. The acceptance level was $77 \%$.

Data collection was carried out in November and December 2006 under standardized conditions as regards the light source, equipment and instruments and the position of the three dentist examiners and the three recorders, who were all previously calibrated over several sessions and obtained a weighted kappa score of $>0.8$ compared to the gold standard.

The examination was performed with the person to be examined sitting on a chair, with his or her neck extended, opposite the examiner. The lighting was constant during the examination process, as a portable whitespectrum lamp was used.

The variables recorded in this study were:

- Community periodontal index (CPI), according to the WHO recommendations, based on 6 teeth $(17 / 16$, $11,26 / 27,36 / 37,31,46 / 47$ ) classed as $0=$ healthy, $1=$ bleeding, $2=$ calculus, $3=3.5-4.4 \mathrm{~mm}$ pocket, or $4=$ $>5.5 \mathrm{~mm}$ pocket.

- Education (primary, secondary or higher).

- Social class, following the Spanish Society of Epidemiology's classification into low, middle or high class based on occupation.

- Immigrant (yes/no)

- Gender (male/female)

- Age

- Smoker (yes/no)

- Alcohol consumption daily (yes/no)

- Tooth brushing daily (yes/no)

- Regular visits to the dentist at least once a year (yes/ no)

- Place of residence (urban/rural).

The sample size calculation was based on the 2005 Spanish epidemiological study estimate of a $25.4 \%$ preva- 
lence of periodontal pockets. For a $95 \%$ confidence level and $3.2 \%$ precision, the estimated sample size was calculated as 722 persons.

Bivariate statistics were calculated with means, proportions and 95\% confidence intervals. Student's T-test was used to compare the means once normal distribution and the proportions had been verified by the Shapiro-Wilk test and the chi-squared test, respectively. Multivariate data analysis was also performed using forward Wald stepwise logistic regression. The significance level was set at $p<0.05$.

\section{Results}

The sample examined consisted of 733 individuals (220 men and 513 women).

Measured by their maximum CPI score, 13\% were healthy, with no sign of periodontal disorders, and 5.5\% presented bleeding. The prevalence of calculus was $59.3 \%$, that of $3.5-5.5 \mathrm{~mm}$ pockets was $15.8 \%$ and that of pockets deeper than $5.5 \mathrm{~mm}$ was $4.6 \%$.

As regards the extent of the disease process, almost half the sextants were healthy (2.89), 0.61 presented bleeding and 1.74 presented calculus. The mean number of sextants with $3.5-5.5 \mathrm{~mm}$ pockets was 0.46 and 0.07 of sextants had deep pockets $(>5.5 \mathrm{~mm})$. The sextants excluded from the CPI calculation numbered 0.23 .

Significant differences in the mean number of sextants with 3.5-5.5 millimetre periodontal pockets were found. They were higher in individuals with a primary education, low social class, male gender, smokers, and who visited the dentist regularly. As regards deep periodontal pockets $(>5.5 \mathrm{~mm})$, the only variable associated with a higher mean number of sextants was low social class (Table 1).

On applying a chi-squared test $(p<0.05)$, an association with a higher prevalence of periodontal pockets was found for primary education, low social class, male gender, smokers, alcohol consumption, no daily tooth brushing and regular visits to the dentist (Table 2).

An adjusted multiple logistic regression model (Hosmer and Lemeshow's test of goodness fit $p=0.295$; \% correctly predicted $=77.4 \%$ ), taking the presence of periodontal pockets as the dependent variable, found that the significant independent variables were low social class, smoking, primary education, male gender and age (Table 3 ). The other study variables were not significant in this model. Table 3 shows the odds ratios (OR), which range between 1.81 and 1.08, and their respective 95\% confidence intervals $(95 \% \mathrm{CI})$.

\section{Discussion}

In this cross sectional study of 733 individuals, the proportion of healthy individuals with no sign of periodontal disorders was $13 \%$, the prevalence of 3.5 to $5.5 \mathrm{~mm}$ pockets was $15.8 \%$ and that of pockets deeper than 5.5 $\mathrm{mm}$ was $4.6 \%$. On comparing these findings with similar studies, $46 \%$ of US adults had periodontitis but only $8.9 \%$ of those affected presented an advanced stage of the disease (12), while a study in a Danish population (13) found low percentages of periodontally-healthy individuals in the 35-44 year-old and 65-74 year-old groups ( $7.7 \%$ and $2.4 \%$, respectively).

In Spain, studies of representative population groups of 35-44 year-olds have found the following proportions of completely healthy individuals: $19.3 \%$ in Llodrá et al. (14), $14.8 \%$ in Bravo et al. (15), 16\% in Llodrá 2012 (16) and 6\% in Carasol et al. (17), although the latter only studied the working population rather than the general population. In the present study of a representative sample of this age group in the Valencia region, the percentage was $13 \%$. As regards the presence of a moderate level of periodontal disease, the CPI 3 results were $21 \%, 21.5 \%, 11 \%$ and $29.2 \%$, respectively, in the above-mentioned studies, and $15.8 \%$ in the present study. Lastly, the above studies found advanced periodontal disease in $4.2 \%, 3.9 \%, 5 \%$ and $8.4 \%$ of their samples, respectively, while the proportion of CPI 4 scores in the present study was $4.6 \%$. These results for the Spanish population also agree with data obtained for the European population (18-20).

Another salient finding is the extent of periodontal disease. On examining the data by sextant, almost half of the sextants were healthy (2.89) and even though 1.74 presented calculus, only 0.46 sextants per individual had periodontal pockets measuring 3.5 to $5.5 \mathrm{~mm}$ and only 0.07 had pockets of over $5.5 \mathrm{~mm}$. These findings are similar to those of other studies $(6-8,21)$.

The present study found that low social class, age, smoking, male gender and primary education were independent variables that showed a significant association with periodontal pockets, while others such as tooth brushing or alcohol were not significant variables for periodontal disease.

Age proved to be a variable that was significantly associated with periodontal conditions, as in other epidemiological studies (12). Carasol et al. (17) associated age with periodontal disease with an OR of 1.43. The OR associated with age in the present study was 1.08 .

Male gender was also related to periodontal disease in this study $(\mathrm{OR}=1.84)$, in agreement $(12,22,23)$ or to a slightly lower extent than the association found by other authors (OR=2.15) in Carasol et al. (17).

On analysing the socio-economic variables, a statistically significant relationship was found between low educational level, low social class and a higher prevalence of periodontal pockets. This agrees with the findings of other studies $(12,13,17,21,24-26)$ confirming the consistency of this association.

With regard to smoking, the OR was 1.68. Philstrom et al. (9) observed that among periodontal patients, 
Table 1: Number of sextants with periodontal pockets, by variables, in a 35-44 year-old population ( $\mathrm{n}=733$ ).

\begin{tabular}{|c|c|c|c|c|c|}
\hline & & $\begin{array}{c}\text { Mean with } \\
\text { periodontal } \\
\text { pockets } \\
(3.5-5.5 \mathrm{~mm})\end{array}$ & $95 \% \mathrm{CI}$ & $\begin{array}{c}\text { Mean with } \\
\text { periodontal } \\
\text { pockets } \\
(>5.5 \mathrm{~mm})\end{array}$ & $95 \% \mathrm{CI}$ \\
\hline \multirow[t]{2}{*}{ Education $^{1}$} & $\begin{array}{c}\text { Primary } \\
\mathrm{n}=177\end{array}$ & 0.69 & $0.50-0.89$ & 0.13 & $0.05-0.21$ \\
\hline & $\begin{array}{c}\text { Secondary -Higher } \\
n=556\end{array}$ & 0.38 & $0.30-0.47$ & 0.05 & $0.03-0.08$ \\
\hline \multirow[t]{2}{*}{ Social Class ${ }^{1,2}$} & $\begin{array}{c}\text { Low } \\
\mathrm{n}=363\end{array}$ & 0.58 & $0.47-0.70$ & 0.11 & $0.06-0.16$ \\
\hline & $\begin{array}{l}\text { Middle-High } \\
\mathrm{n}=370\end{array}$ & 0.34 & $0.24-0.44$ & 0.03 & $0.01-0.06$ \\
\hline \multirow[t]{2}{*}{ Immigrant } & $\begin{array}{c}\text { Yes } \\
n=107\end{array}$ & 0.46 & $0.26-0.65$ & 0.05 & $0.00-0.10$ \\
\hline & $\begin{array}{c}\text { No } \\
n=626\end{array}$ & 0.46 & $0.38-0.54$ & 0.08 & $0.04-0.11$ \\
\hline \multirow[t]{2}{*}{ Gender $^{1}$} & $\begin{array}{c}\text { Male } \\
\mathrm{n}=220\end{array}$ & 0.66 & $0.49-0.83$ & 0.10 & $0.05-0.16$ \\
\hline & $\begin{array}{c}\text { Female } \\
n=513\end{array}$ & 0.37 & $0.29-0.45$ & 0.06 & $0.01-0.12$ \\
\hline \multirow[t]{2}{*}{ Smoker $^{1}$} & $\begin{array}{c}\text { Yes } \\
\mathrm{n}=240\end{array}$ & 0.71 & $0.54-0.87$ & 0.10 & $0.05-0.16$ \\
\hline & $\begin{array}{c}\text { No } \\
n=493\end{array}$ & 0.37 & $0.29-0.42$ & 0.06 & $0.03-0.09$ \\
\hline \multirow[t]{2}{*}{ Alcohol } & $\begin{array}{c}\text { Yes } \\
\mathrm{n}=108\end{array}$ & 0.65 & $0.42-0.88$ & 0.12 & $0.04-0.20$ \\
\hline & $\begin{array}{c}\text { No } \\
\mathrm{n}=625\end{array}$ & 0.43 & $0.35-0.51$ & 0.06 & $0.03-0.09$ \\
\hline \multirow[t]{2}{*}{ Tooth brushing } & $\begin{array}{c}\text { Yes } \\
\mathrm{n}=659\end{array}$ & 0.44 & $0.36-0.52$ & 0.06 & $0.04-0.09$ \\
\hline & $\begin{array}{c}\text { No } \\
\mathrm{n}=74\end{array}$ & 0.62 & $0.36-0.88$ & 0.14 & $0.00-0.28$ \\
\hline \multirow[t]{2}{*}{$\begin{array}{l}\text { Visits dentist } \\
\text { regularly }{ }^{1}\end{array}$} & $\begin{array}{c}\text { Yes } \\
\mathrm{n}=510\end{array}$ & 0.53 & $0.43-0.63$ & 0.07 & $0.04-0.10$ \\
\hline & $\begin{array}{c}\text { No } \\
n=223\end{array}$ & 0.30 & $0.14-0.42$ & 0.06 & $0.01-0.12$ \\
\hline \multirow[t]{2}{*}{ Residence } & $\begin{array}{l}\text { Urban } \\
\mathrm{n}=502\end{array}$ & 0.42 & $0.36-0.54$ & 0.08 & $0.05-0.11$ \\
\hline & $\begin{array}{l}\text { Rural } \\
n=231\end{array}$ & 0.48 & $0.33-0.62$ & 0.06 & $0.01-0.11$ \\
\hline
\end{tabular}

${ }^{1}$ Significant differences $(p<0.05)$ in mean sextants with periodontal pockets according to Student's t-test.

${ }^{2}$ Significant differences $(p<0.05)$ in mean sextants with periodontal pockets according to Student's t-test.

smokers were five times more likely than non-smokers to present deep pockets (OR 5.3). In the present study, the sample represented the general population, not only periodontal patients, and the results confirm the great importance of smoking as a factor associated with periodontal pockets, since smokers were twice as likely to present them. Other more recent studies $(17,24,27)$ have also reasserted the relationship between smoking and more severe periodontal disease.

Regular visits to the dentist are a factor that is related significantly to the presence of periodontal pockets, as those who visited the dentist regularly presented higher 
Table 2: Factors associated with periodontal pockets in a 35-44 year-old population.

\begin{tabular}{|c|c|c|c|}
\hline & & $\begin{array}{c}\text { Prevalence of periodontal } \\
\text { pockets } \\
(95 \% \mathrm{CI})\end{array}$ & $\begin{array}{c}\text { Prevalence } \\
\text { Odds Ratio } \\
(95 \% \text { CI })\end{array}$ \\
\hline \multirow[t]{2}{*}{ Education* } & $\begin{array}{c}\text { Primary } \\
n=177\end{array}$ & $\begin{array}{c}32.8 \% \\
(25.9-40.2)\end{array}$ & \multirow{2}{*}{$\begin{array}{c}2.09 \\
(1.43-3.05)\end{array}$} \\
\hline & $\begin{array}{c}\text { Secondary -Higher } \\
n=556\end{array}$ & $\begin{array}{c}18.9 \% \\
(15.7-22.4)\end{array}$ & \\
\hline \multirow[t]{2}{*}{ Social Class* } & $\begin{array}{c}\text { Low } \\
n=363\end{array}$ & $\begin{array}{c}28.7 \% \\
(24.1-33.6)\end{array}$ & \multirow{2}{*}{$\begin{array}{c}2.11 \\
(1.47-3.03)\end{array}$} \\
\hline & $\begin{array}{l}\text { Middle-High } \\
n=370\end{array}$ & $\begin{array}{c}15.9 \% \\
(12.4-20.1)\end{array}$ & \\
\hline \multirow[t]{2}{*}{ Immigrant } & $\begin{array}{c}\text { Yes } \\
\mathrm{n}=107\end{array}$ & $\begin{array}{c}24.3 \% \\
(16.5-33.5)\end{array}$ & \multirow{2}{*}{$\begin{array}{c}1.14 \\
(0.70-1.85)\end{array}$} \\
\hline & $\begin{array}{c}\text { No } \\
n=626\end{array}$ & $\begin{array}{c}21.9 \% \\
(18.7-25.3)\end{array}$ & \\
\hline \multirow[t]{2}{*}{ Gender $^{*}$} & $\begin{array}{c}\text { Male } \\
\mathrm{n}=220\end{array}$ & $\begin{array}{c}30.0 \% \\
(24.0-36.5)\end{array}$ & \multirow{2}{*}{$\begin{array}{c}1.83 \\
(1.27-2.64)\end{array}$} \\
\hline & $\begin{array}{c}\text { Female } \\
\mathrm{n}=513\end{array}$ & $\begin{array}{c}18.9 \% \\
(15.6-22.5)\end{array}$ & \\
\hline \multirow[t]{2}{*}{ Smoker" } & $\begin{array}{c}\text { Yes } \\
n=240\end{array}$ & $\begin{array}{c}31.3 \% \\
(25.4-37.5)\end{array}$ & \multirow{2}{*}{$\begin{array}{c}2.09 \\
(0.75-2.35)\end{array}$} \\
\hline & $\begin{array}{c}\text { No } \\
n=493\end{array}$ & $\begin{array}{c}17.8 \% \\
(14.5-21.5)\end{array}$ & \\
\hline \multirow[t]{2}{*}{ Alcohol* } & $\begin{array}{c}\text { Yes } \\
\mathrm{n}=108\end{array}$ & $\begin{array}{c}31.5 \% \\
(22.8-41.1)\end{array}$ & \multirow{2}{*}{$\begin{array}{c}1.76 \\
(1.12-2.77)\end{array}$} \\
\hline & $\begin{array}{c}\text { No } \\
n=625\end{array}$ & $\begin{array}{c}20.6 \% \\
(17.5-24.0)\end{array}$ & \\
\hline \multirow[t]{2}{*}{ Tooth brushing* } & $\begin{array}{c}\text { Yes } \\
n=659\end{array}$ & $\begin{array}{c}35.1 \% \\
(24.3-47.1)\end{array}$ & \multirow{2}{*}{$\begin{array}{c}2.06 \\
(1.23-3.44)\end{array}$} \\
\hline & $\begin{array}{c}\text { No } \\
n=74\end{array}$ & $\begin{array}{c}20.8 \% \\
(17.7-24.1)\end{array}$ & \\
\hline \multirow[t]{2}{*}{ Visits dentist regularly* } & $\begin{array}{c}\text { Yes } \\
\mathrm{n}=510\end{array}$ & $\begin{array}{c}25.7 \% \\
(21.9-29.7)\end{array}$ & \multirow{2}{*}{$\begin{array}{c}2.07 \\
(1.35-3.15)\end{array}$} \\
\hline & $\begin{array}{c}\text { No } \\
n=223\end{array}$ & $\begin{array}{c}14.3 \% \\
(10.0-19.6)\end{array}$ & \\
\hline \multirow[t]{2}{*}{ Residence } & $\begin{array}{l}\text { Urban } \\
\mathrm{n}=502\end{array}$ & $\begin{array}{c}22.3 \% \\
(18.7-26.2)\end{array}$ & \multirow{2}{*}{$\begin{array}{c}1.01 \\
(0.69-1.47)\end{array}$} \\
\hline & $\begin{array}{l}\text { Rural } \\
\mathrm{n}=231\end{array}$ & $\begin{array}{c}22.1 \% \\
(16.9-27.8)\end{array}$ & \\
\hline
\end{tabular}

* Significant association $(P<0.05)$ according to the Chi squared test.

percentages of pockets ( $25.7 \%$ compared to $14.3 \%$ ). The relationship between visiting the dentist regularly and a higher percentage of periodontal pockets is understandable, since these could be one of the main reasons for making such visits in the first place. In a young population group, Krustrup et al. (13) also observed a greater prevalence of periodontal pockets among patients who visited the dentist regularly.

An aspect of the present study that should be borne in mind is the large and representative size of the sample, which makes it possible to extrapolate its findings to the adult population of the Valencia region. As regards its limitations, one is the absence of radiographic records which would show the bone loss resulting from periodontal disease, although these are not indicated in epidemiological studies and the main variable is therefore periodontal pockets. Another is that the quantity of tobacco smoked was not recorded, as some studies $(9,17)$ have shown that heavy smokers present greater progression of the disease than those who smoke less. Also, as is 
Table 3: Multiple logistic regression model with periodontal disease as the dependent variable in a 35-44 year-old population.

\begin{tabular}{|l|c|c|c|}
\hline Independent variables & $\begin{array}{c}\text { Prevalence } \\
\text { OR }\end{array}$ & $\mathbf{9 5 \% \mathbf { C I }}$ & $\begin{array}{c}\text { Wald } \\
\boldsymbol{p} \text {-value }\end{array}$ \\
\hline Social Class low vs middle-high & 1.81 & $1.21-2.69$ & 0.004 \\
\hline Smoking & 1.68 & $1.15-2.47$ & 0.007 \\
\hline Education primary vs secondary-higher & 1.57 & $1.03-2.38$ & 0.034 \\
\hline Gender male vs female & 1.56 & $1.04-2.35$ & 0.032 \\
\hline Age & 1.08 & $1.03-1.13$ & 0.001 \\
\hline
\end{tabular}

CI: confidence interval; OR: odds ratio, $\mathrm{R}^{2}$ Nagelkerke $=0.12 ; \mathrm{n}=733$.

well known, periodontal disease is not uniformly distributed throughout the different teeth in the mouth. Consequently, the screening protocols normally employed in epidemiological studies, like the CPI, may underestimate the prevalence of periodontal disease $(17,28)$.

To conclude, it may be stated that this study of a representative sample of the population of the Valencia region of Spain shows that periodontal disease is related to a series of socio-economic factors such as low educational level and social class, as well as with male gender, age and smoking. It would therefore appear to be evident that the adult population of the Valencia region includes risk groups in need of health education, prevention and treatment.

\section{References}

1. Armitage GC. Clinical evaluation of periodontal diseases. Periodontol 2000. 1995;7:39-53.

2. Bravo M, Almerich JM, Ausina V, Avilés P, Blanco JM, Canorea E, et al. Encuesta de Salud Oral en España 2015. RCOE. 2016;21:8-48.

3. Armitage GC. Development of a classification system for periodontal diseases and conditions. Ann Periodontol. 1999;4:1-6.

4. Highfield J. Diagnosis and classification of periodontal disease. Aust Dent J. 2009;54:S11-S26.

5. Löe H, Anerud A, Boysen H, Morrison E. Natural history of periodontal disease in man. Rapid, moderate and no loss of attachment in Sri Lankan laborers 14 to 46 years of age. J Clin Periodontol. 1986;13:431-40.

6. Badersten A, Nilveus R and Egelberg, J. Effect of Non-surgical Periodontal Therapy. VII Bleeding, Suppuration and Probing Depth in Sites with Probing Attachment Loss. J Clin Periodontol. 1985;12:43240.

7. Lang NP, Joss A, Orsanic T, Gusberti FA, Siegrist BE. Bleeding on probing. A predictor of the progresión of periodontal disease? J Clin Periodontol. 1986;13:590-6.

8. Griffiths GS, Wilton JMA, Curtis MA, Maiden MFJ, Gillett IR, Wilson DT, et al. Detection of High-risk Groups and Individuals for Periodontal Diseases. Clinical Assessment of the Periodontium. J Clin Periodontol. 1988;15:403-10.

9. Philstrom BL. Periodontal risk assessment, diagnosis and treatment planning. Periodontol 2000. 2001;25:37-58.

10. Preber H, Bergström J. Occurrence of gingival bleeding in smoker and non-smoker patients. Acta Odontol Scand. 1985;43:315-20.

11. Socransky SS, Haffajee A, Cugini MA, Smith C, Kent Jr. R. Microbial complexes in subgingival plaque. J Clin Periodontol. 1998;25:13444.
12. Eke PI, Dye BA, Wei L, Slade GD, Thornton-Evans GO, Borgnakke WS, et al. Update on Prevalence of Periodontitis in Adults in the United States: NHANES 2009 to 2012. J Periodontol. 2015;86:61122

13. Krustrup U, Petersen E. Periodontal conditions in 35-44 and 6574-year-old adults in Denmark. Acta Odontol Scand. 2006;64:65-73.

14. Llodra, J, Bravo, M, Cort es, F. Encuesta de Salud Oral en España (2000). RCOE. 2002;7:1-57.

15. Bravo M, Casals E, Cortes F, Llodra J. Encuesta de Salud Oral en España 2005. RCOE. 2006;11:409-56.

16. Llodra J. Encuesta de salud oral en España 2010. RCOE. 2012;17:13-41.

17. Carasol M, Llodra JC, Fernandez-Meseguer A, Bravo M, GarciaMargallo MT, Calvo-Bonacho E, et al. Periodontal conditions among employed adults in Spain. J Clin Periodontol. 2016;43:548-56.

18. Petersen, P. E. \& Ogawa, H. The global burden of periodontal disease: towards integration with chronic disease prevention and control. Periodontol 2000. 2012;60:15-39.

19. Kassebaum NJ, Bernabe E, Dahiya M, Bhandari B, Murray CJ, Marcenes W. Global burden of severe periodontitis in 1990-2010: a systematic review and meta- regression. J Dent Res. 2014;93:104553.

20. Sheiham A, Netuveli GS. Periodontal diseases in Europe. Periodontol 2000. 2002;29:104-21.

21. Zini A, Sgan-Cohen HD, Marcenes W. Socio-economic position, smoking, and plaque: a pathway to severe chronic periodontitis. J Clin Periodontol. 2011;38:229-35.

22. Hermann P, Gera I, Borbely J, Fejerdy P, Madlena M. Periodontal health of an adult population in Hungary: findings of a national survey. J Clin Periodontol. 2009;36:449-57.

23. Holtfreter B, Schwahn, CH, Biffar R, Kocher TH. Epidemiology of periodontal diseases in the study of health in Pomerania. J Clin Periodontol. 2009;36:114-23.

24. Prasanna HR, Chandan DN, Kripal K, Hari KR, Adarsh CM, Reddy TP. A cross-sectional study on the relationship between behavioral variables and economic status in periodontal disease among elderly individuals. J Contemp Dent Pract. 2012;13:699-702.

25. Boillot A, El Halabi B, Batty GD, Rangé H, Czernichow S, Bouchard P. Education as a predictor of chronic periodontitis: a systematic review with meta-analysis population-based studies. PLoS One. 2011;6:e21508.

26. Borrell LN, Beck JD, Heiss G. Socioeconomic disadvantage and periodontal disease: the Dental Atherosclerosis Risk in Communities study. Am J Public Health. 2006;96:332-9.

27. Genco RJ, Borgnakke WS. Risk factors for periodontal disease. Periodontol 2000. 2013;62:59-94.

28. Beck JD, Caplan DJ, Preisser JS, Moss K. Reducing the bias of probing depth and attachment level estimates using random partialmouth recording. Community Dent Oral Epidemiol. 2006;34:1-10. 
Acknowledgements

The authors wish to thank Mary-Georgina Hardinge for translating the manuscript into English.

\section{Conflict of Interest}

The authors declare that they have no conflict of interest 